A N N A LES

UNIVERSITATIS MARIAE CURIE-SKŁODOWSKA LUBLIN - POLONIA

VOL. LXIX, 1

SECTIO B

2014

Faculty of Earth Sciences and Spatial Management, Maria Curie-Skłodowska University

GRZEGORZ JANICKI

\title{
Transformation of upland wash slope - a case study from the Lublin Upland (SE Poland)
}

Przeobrażenia wyżynnego stoku zmywowego na przykładzie Wyżyny Lubelskiej (południowo-wschodnia Polska)

Keywords: slopewash processes, extreme events, microforms, relief upland development

Słowa kluczowe: zmyw powierzchniowy, zdarzenia ekstremalne, mikrorzeźba, rzeźba efemeryczna, rozwój rzeźby wyżynnej

\section{INTRODUCTION}

Slopes do not constitute independent geomorphological systems. Due to their relation and belonging to specific groups of relief macroforms, they are subject to the same development patterns in a long timescale (geological time) as the superior form in a specific morphogenetic zone. Therefore, they are usually polygenetic, and seldom, only within "young" forms, homogenous. The slope relief includes a record of their geological past, individual development stages, and processes shaping slopes. The record constitutes a response of the system to changing environmental conditions, and particularly a manifestation of their adjustment to tectonic, climatic or land cover changes (Davis 1899; Dylik 1969).

In short periods of time (geomorphological time), slopes can be recognised as relatively autonomous (independent), natural environmental systems, distinguished by their own development patterns, different than those of e.g. river valleys or gullies. Their development is determined by local factors, e.g. lithology of the bedrock underlying slopes, or degree of their fragmentation. Those factors, related to the state of evolution of the environment, can be treated as independent in the discussed timescale. The second factor, indirectly related to "geology", is land cover and land use, determined in the Neoholocene by human activity. It seems that especially currently, the anthropogenic factor determines the condi- 
tions and rate, as well as directions of relief development, at least for settled areas. In the modern times, in the intermediate climate conditions of temperate zone, forested slopes are distinguished by high stability and very low intensity of modern morphogenetic processes, where decalcification dominates (Maruszczak 1986; Starkel 1986; Rodzik et al. 2008).

Slopes with no forest cover, and those occupied by agricultural fields behave differently. In areas subject to agricultural use, slope development conditions become similar to those occurring in the semi-arid zone (warm half-year) or tundra (cold half-year). Landscape "steppisation" and "tundration" is "accelerated" by adjustment of slope systems to new conditions. Additionally, the long-lasting agricultural activity disturbed the dynamic balance of the slope, and resulted in the development of new landforms. Anthropogenic relief and tillage erosion change the conditions of overland flow to a significant degree, and affect the direction of slope development (Gerlach 1966; Lach 1984; Twardy 1995; Poesen et al. 2003; Rejman 2006). The co-occurrence of those factors is reflected particularly during the intensive slopewash caused by violent downpours and snow melt. Activated slopewash processes are responsible for modern shaping of slopes subject to agricultural use in the temperate morphoclimatic domain, particularly slopes developed on soft Quaternary deposits, hardly resistant to erosion. These slopes are called slopewashes (Kirkby 1971, 1978; Teisseyre 1994; Janicki 2002).

The objective of the paper is to determine the intensity of modern slopewash processes, and to estimate their effect on the development of slopes under agricultural use, lying on loess and like-loess deposits, in various landscape types of the Lublin Upland (sensu lato). The role of extreme events in the functioning of slope systems in short time period was also estimated. According to a number of scholars, those events determine the rate and direction of development of geomorphological systems (Starkel 1976, 1986; Brunsden 1996).

\section{STUDY AREA}

\section{Geological-morphological conditions}

The area between the Vistula and Bug rivers, including the eastern part of the Polish Uplands (Fig. 1), is sometimes recognised as belonging to the European Mid Mountains, stretching from the Massif Central to the region of Podolia (Wojtanowicz 1999). That eastern part of the Polish Uplands is called the Lublin Upland which includes block morphostructures of the Cambrian platform on which tabular- or platform-type uplands developed, not exceeding $390 \mathrm{~m}$ a.s.1. The geological substratum of the region is the Permian-Cretaceous sediment rock formation. The most important morphogenetic function is fulfilled by diversified Late Cretaceous marine lithophacies deposits (opokas, gaizes, marls, chalk), con- 
stituting a continuous cover with a thickness from 350 to $1,400 \mathrm{~m}(800 \mathrm{~m}$ on the average). Cainozoic sediments, covering Cretaceous rocks in a discontinuous manner, have an insignificant thickness below a few tens of meters. Tertiary and Quaternary rocks are responsible for only subordinate natural environment and landscape features. Tertiary sediments (limestones and sandstones) occur in isolated aggregates, and constitute inselbergs of the Neogene relief. Quaternary sediments are represented particularly by moraine tills and loesses. Loesses, mainly Vistulian, develop dense covers (thickness $>3 \mathrm{~m}$ ) and patches within the area of elevated and shaped surfaces (approximately $30 \%$ of the region in total) (Maruszczak 1972, 2001).

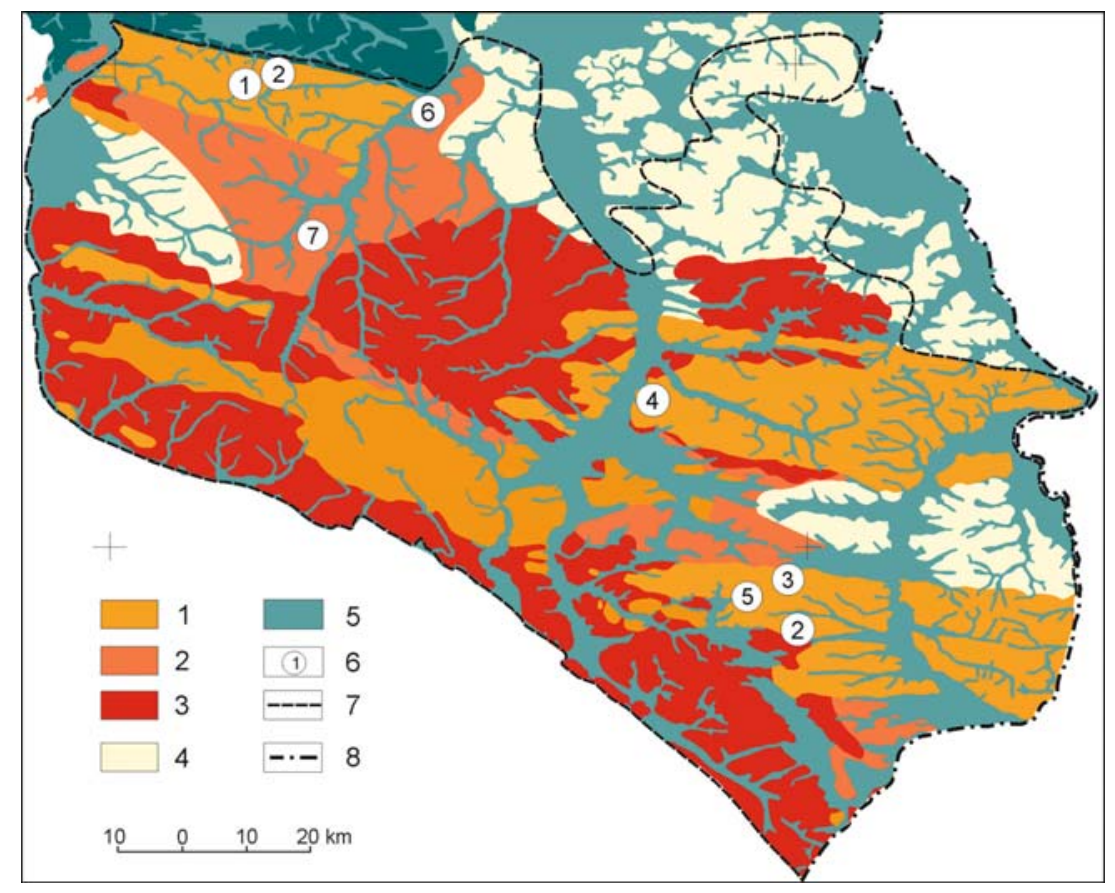

Fig. 1. Localization of the study areas against the Lublin Upland landscapes background (after Janicki 2002): 1 - loess landscape, 2 - carbonaceous-siliceous landscape, 3 - siliceouscarbonaceous landscape, 4 - carbonaceous landscape, 5 - alluvial landscape, 6 - research areas, 7 - boundary of the Lublin Upland region (after H. Maruszczak 1972), 8 - state boundary

The wash slopes of the Lublin Upland area were inherited after previous landscape cycles. They clearly reflect Neogene morphogenesis responsible for the surface development of (hilltop and slope) levellings with a character of pediments and structural ridges, as well as for development of inselberg hills and river valleys (the Pliocene and Eopleistocene). During the Pleistocene morphogenesis, 
some slopes were destroyed or buried, and some were transformed into dry flatbottom valleys. The best developed dry valleys of the type occur in siliceouscarbonaceous (elevations, hilltops, and hummocks) and carbonaceous-siliceous areas (planes and plateaus). Within thicker loess covers, periglacial processes initiated the development of a network of dry erosion-denudation valleys (in German: Tilke) and trough valleys of the Delle type. Profiles of inherited slopes are mature and levelled, dominated by convex-concave and uniform, convergent and divergent slopes (Jahn 1956; Maruszczak 1972, 2001; Harasimiuk 1980).

During the Holocene, slopes were stabilised by the appearing forest vegetation (mesophilous mixed climax forests). Erosion-denudation forms of gully type have divided those slopes in the Neoholocene as a result of the very first farming activity (Maruszczak 1972, 1973; Buraczyński 1992; Starkel 2005; Rodzik et al. 2008). A change in the conditions of slope development, resulting from longlasting cultivation, caused the development of slope wash forms (ablation troughs) and so-called agrotechnical denudation forms, currently appearing to play a significant morphological role. The development of gorge forms like: sub-dissections, indentations, dissections, troughs, dikes, and cultivation-related forms (scarps and terraces) leads to fragmentation and change in the slope profile (Rodzik 1999, 2000; Zgłobicki 2002; Rodzik et al. 2008).

\section{Climatic conditions}

The Lublin Upland belongs to the temperate morphoclimatic domain, distinguished by its transitional character with oceanic and continental influences, which is manifested by high changeability of whether types in the annual, seasonal, and daily cycles. Amplitudes of mean annual temperatures, from 1951 to 2000, were usually $21-22^{\circ} \mathrm{C}$, and sometimes reached $24^{\circ} \mathrm{C}$. Mean annual air temperature in Lublin varied from $6.9^{\circ} \mathrm{C}$ to $9.8^{\circ} \mathrm{C}\left(7.4^{\circ} \mathrm{C}\right.$ on the average). The warmest month was usually July with mean temperatures from $14.3^{\circ} \mathrm{C}$ to $20.9^{\circ} \mathrm{C}\left(18.7^{\circ} \mathrm{C}\right.$ on the average). The coldest month tended to be January $\left(-3.0^{\circ} \mathrm{C}\right.$ on the average), but the lowest multi-annual temperature occurred in February $\left(-12.5^{\circ} \mathrm{C}\right)$. The duration of the vegetative period varied between 194 and 328 days (214 days on the average), and frost occurred during 42 days per year. The influence of continental climate was particularly reflected in the differential of annual precipitation totals reaching the values from $338 \mathrm{~mm}$ (1976) to $808 \mathrm{~mm}$ (1974), and averaged $541 \mathrm{~mm}$. Maximum precipitation usually occurred in July ( $79 \mathrm{~mm}$ on the average), and minimum in January, February, or March (26 mm on the average). The highest monthly precipitation totals $(205 \mathrm{~mm})$, however, were recorded in October 1974. Precipitation in the warm half-year averaged $346 \mathrm{~mm}$ ( $>60 \%$ of the annual total), and varied from $158 \mathrm{~mm}$ (1982) to $675 \mathrm{~mm}$ (1974). Potentially, snow cover can develop from October to April. The usually dense cover was maintained from 
24 November to 24 March. The mean number of days with snow cover was 73, max. 119, and min. 22 (Kaszewski et al. 1995; Kaszewski 2008).

Additionally, the Lublin Upland area was distinguished by high changeability of downpours with high efficiency, resulting in local high water and flash floods in river valleys, and significant slope transformations. Similar effects have resulted from violent snowmelts, distinguished by (quasi) periodicity (Rodzik, Janicki 2003; Rodzik et al. 2008; Janicki et al. 2010).

\section{Land use}

The Lublin Upland is a remarkably agricultural region, where agricultural land constitutes over $70 \%$ of the area, and forests approximately $15 \%$. Agricultural land is dominated by arable land. Traditional grain cultivation is predominating, with a significant participation of potatoes and sugar-beets. During the last few years, an increase in the area of cultivation of rape and papilionaceous plants has been observed. The agricultural structure is dominated by family homesteads occupying approx. 90\% of all agricultural land (Statistical Yearbook of Agriculture, 2010, GUS, Warsaw). Agricultural homesteads are usually small (averaging $7.6 \mathrm{ha}$ ) and scattered, which results in a typical mosaic of fields and crops, and high density of boundaries of arable plots (in Polish: miedza) and numerous access roads, fulfilling an important function in the organisation of overland flow.

Agricultural land consolidation processes, an increase in mechanisation of agriculture, and its industrialisation, are currently observed in the Lublin region. On the other hand, depopulation processes and the economic crisis contributed to land abandonment (so-called set-aside, fallow land) in less fertile areas or areas difficult for cultivation, and an increase in established forest areas.

\section{Study areas}

For the analysis of functioning of the slopewash system, seven study areas were selected, representative of various types of upland relief and landscape of the Lublin Upland (Fig. 1). The selection of those areas was mainly determined by the occurrence of extreme events such as violent downpours in the period 1995-2000. The areas analysed were usually located in the centre of the abovementioned events, due to which the intensity of the resulting overland flow and its geomorphological effects were the most significant. In the loess areas, five study areas were located: Kolonia Gutanów (1), Garbów (2), Zubowice (3), Krasne (4), and Krynice (5), representing loess plateaus and hilltops dissected to a small degree, or with a weakly developed network of erosion dissections (gullies). Two areas, Turka (6) and Niedrzwica Duża (7), represent the type of plains and denudation plateaus developed on carbonaceous-siliceous substratum. Table 1 presents the main morphometric features of the study areas analysed. 
Table 1. Morphometric features of the study areas

\begin{tabular}{|c|c|c|c|c|c|c|c|c|c|c|c|}
\hline \multirow{2}{*}{ No. } & \multirow{2}{*}{ Study areas } & \multirow{2}{*}{ Relief } & \multirow{2}{*}{$\begin{array}{l}\text { Valley } \\
\text { slope } \\
{[\mathrm{m} / \mathrm{m}]}\end{array}$} & \multirow{2}{*}{$\begin{array}{l}\text { Heights } \\
\frac{H \max }{H \min } \bar{H} \\
{[\mathrm{~m} \text { a.s.1.] }}\end{array}$} & \multicolumn{2}{|c|}{$\begin{array}{l}\text { Denivela- } \\
\text { tions }\end{array}$} & \multicolumn{2}{|c|}{$\begin{array}{l}\text { Slope } \\
\text { length }\end{array}$} & \multicolumn{3}{|c|}{ Catchment } \\
\hline & & & & & $\begin{array}{c}\max \\
{[\mathrm{m}]}\end{array}$ & $\begin{array}{c}\text { med } \\
{[\mathrm{m}]}\end{array}$ & $\begin{array}{l}\max \\
{[\mathrm{m}]}\end{array}$ & $\begin{array}{c}\text { med } \\
{[\mathrm{m}]}\end{array}$ & $\begin{array}{c}L \\
{[\mathrm{~km}]}\end{array}$ & $\begin{array}{c}A \\
{\left[\mathrm{~km}^{2}\right]}\end{array}$ & $\begin{array}{c}S \\
{\left[{ }^{\circ}\right]}\end{array}$ \\
\hline 1 & $\begin{array}{l}\text { Kolonia } \\
\text { Gutanów }\end{array}$ & Delle & 0.021 & $\frac{220.2}{190} 205$ & 30.2 & 15 & 1500 & 900 & 1.55 & 0.02 & $5-10$ \\
\hline 2 & Garbów & $\begin{array}{l}\text { loess } \\
\text { plateau }\end{array}$ & - & $\frac{231}{172.9} 201.9$ & 58.1 & 29 & 500 & 225 & - & 2.54 & $<10$ \\
\hline $2 \mathrm{a}$ & Garbów I & Tilke & 0.016 & $\frac{231}{172.9} 201,9$ & 58.1 & 29 & 500 & 300 & 2.4 & 1.84 & $<10$ \\
\hline $2 b$ & Garbów II & Tilke & 0.022 & $\frac{223.2}{180} 201.6$ & 43.2 & 20 & 370 & 250 & 1.5 & 0.7 & $<10$ \\
\hline 3 & Zubowice & $\begin{array}{l}\text { loess } \\
\text { plateau }\end{array}$ & - & $\frac{298}{210.7} 254.3$ & 87.3 & 43 & 1000 & 600 & - & 39.3 & $5-10$ \\
\hline $3 a$ & Komarów & Tilke & $\begin{array}{l}0.008 \\
0.016\end{array}$ & $\frac{298}{210.7} 254.3$ & 87.3 & 43 & 1000 & 250 & 11 & 23.8 & $5-10$ \\
\hline $3 b$ & Zubowice & $\begin{array}{l}\text { loess } \\
\text { escarp- } \\
\text { ment }\end{array}$ & - & $\frac{282.8}{210} 246.2$ & 82.8 & 36 & 1200 & 1000 & 17.3 & 15.5 & 5 \\
\hline 4 & Krasne & Tilke & 0.035 & $\frac{288.5}{214.16} 251$ & 74 & 36.8 & 700 & 500 & 2 & 3 & $5-10$ \\
\hline 5 & Krynice & Delle & 0.022 & $\frac{320}{273.4} 297.2$ & 46.6 & 22.8 & 1000 & 500 & 1.94 & 0.8 & $>5$ \\
\hline 6 & Turka & Delle & 0.014 & $\frac{205}{160} 190$ & $>45$ & 22.5 & 1600 & 900 & 4 & 5.7 & $3-5$ \\
\hline 7 & $\begin{array}{l}\text { Niedrzwica } \\
\text { Duża }\end{array}$ & $\begin{array}{l}\text { denu- } \\
\text { dative } \\
\text { plateau }\end{array}$ & - & $\frac{236.25}{187.8} 212$ & 48.4 & 24 & 1000 & 600 & 2.4 & - & - \\
\hline $7 \mathrm{a}$ & $\begin{array}{l}\text { Niedrzwi- } \\
\text { ca I }\end{array}$ & $\begin{array}{l}\text { denu- } \\
\text { dative } \\
\text { trough }\end{array}$ & 0.01 & $\frac{236.25}{192.1} 214$ & 44.1 & 26.2 & 500 & 200 & 3.2 & 3.7 & $<5$ \\
\hline $7 b$ & $\begin{array}{l}\text { Niedrzwi- } \\
\text { ca II }\end{array}$ & $\begin{array}{l}\text { denu- } \\
\text { dative } \\
\text { trough }\end{array}$ & 0.01 & $\frac{231.5}{187.8} 209$ & 43.7 & 21.2 & 1000 & 400 & 3.3 & 4.6 & $<5$ \\
\hline
\end{tabular}

$L$ - length, $A$ - area, $S$ - average inclination 


\section{METHODS}

The field research was conducted in the years 1995-2000 in the Lublin Upland area. It involved registration of extreme events such as violent downpours, and analysis of the functioning of the slope system during those events. Listing of results of the events analysed was conducted with the application of the post factum technique. Direct research was not possible, with the exception of one case (downpour on 15 June 2000) which did not reach the efficiency of a typical violent downpour. In the remaining cases, efforts were taken in order to conduct listing of results of extreme events directly after their occurrence, due to the ephemeral character of the resulting forms. The forms were further monitored until their disappearance as a result of ploughing or purposeful nivelation works.

The height, intensity, and range of the downpours analysed were determined based on precipitation stations of the national Institute of Meteorology and Water Management, and meteorological stations of the Maria Curie-Skłodowska University and University of Life Sciences in Lublin. The maximum efficiency of downpours was estimated based on diurnal precipitation totals, and interpolated based on registration of the hydrological and geomorphological effects.

The resulting land forms and activated morphological processes were listed based on the geomorphological mapping method. Basic morphometric parameters such as length, width, and thickness/depth were measured for large forms (with a diameter of $>1 \mathrm{dm}^{3}$ ). Small forms were not measured for technical reasons, but were included in the geomorphological map. Results of geomorphological mapping were presented on a topographic base map at the scale of 1:10,000. In special cases, enhanced base maps were applied.

Erosion and deposition rates were estimated based on measurement of the volume of the resulting forms. In calculations of the volume of the forms mapped, due to practical reasons, mean width and mean depth/thickness of the forms analysed, determined for sectors with similar cross-sections, were applied. In the erosion/deposition budget of the study areas, linear erosion (rill and channel erosion) and deposition were calculated directly as a result of measurement of the volume of the forms. In the case of positive erosion/deposition budget, total erosion was calculated by increasing the value of linear erosion by the value of the difference between deposition and linear erosion. Due to technical reasons, the budget did not include the value of material deposition in the mid-slope position. Values of this type of deposition are relatively insignificant and omitted. Due to technical reasons, data listed in the erosion/deposition budget are only tentative, presenting the level of values, and informing on the scale of a given event.

In order to confirm the slope relief transformation directions predominating in a geomorphological timescale, soil transects were carried out for selected study 
areas. Based on a field analysis of soil transects, zones of reduction and extension of the soil profile, and indirectly the place of dominance or erosion or deposition, were determined in accordance with the methodology by Zachar (1982).

\section{RESULTS}

\section{Climatic conditions}

The period 1995-2000, in which the study was conducted, was distinguished by exceptionally high changeability of air temperatures and precipitation totals in the annual and seasonal cycles (Fig. 2). Mean air temperatures of the winter half-year in Lublin ranged between $-2.2^{\circ} \mathrm{C}$ by 1996 and $2.3^{\circ} \mathrm{C}$ in 1998 . The summer half-year was colder than the multi-annual data. The minimum mean monthly temperature occurred in January or December, and the maximum occurred in August and June. In the period analysed, a clear increase in annual precipitation totals was recorded. In 1996, the precipitation sum was lower than the multiannual mean precipitation by $16 \mathrm{~mm}$, but in 1998, it exceeded the mean value by $110 \mathrm{~mm}$. The maximum precipitation occurred in various months: May, July, and June. High annual changeability in precipitation was also observed, e.g. in June 1997, the measurement amounted to $36 \mathrm{~mm}$, and in June $1998-106 \mathrm{~mm}$; in July $1996-61 \mathrm{~mm}$, and in July $1997-200 \mathrm{~mm}$.

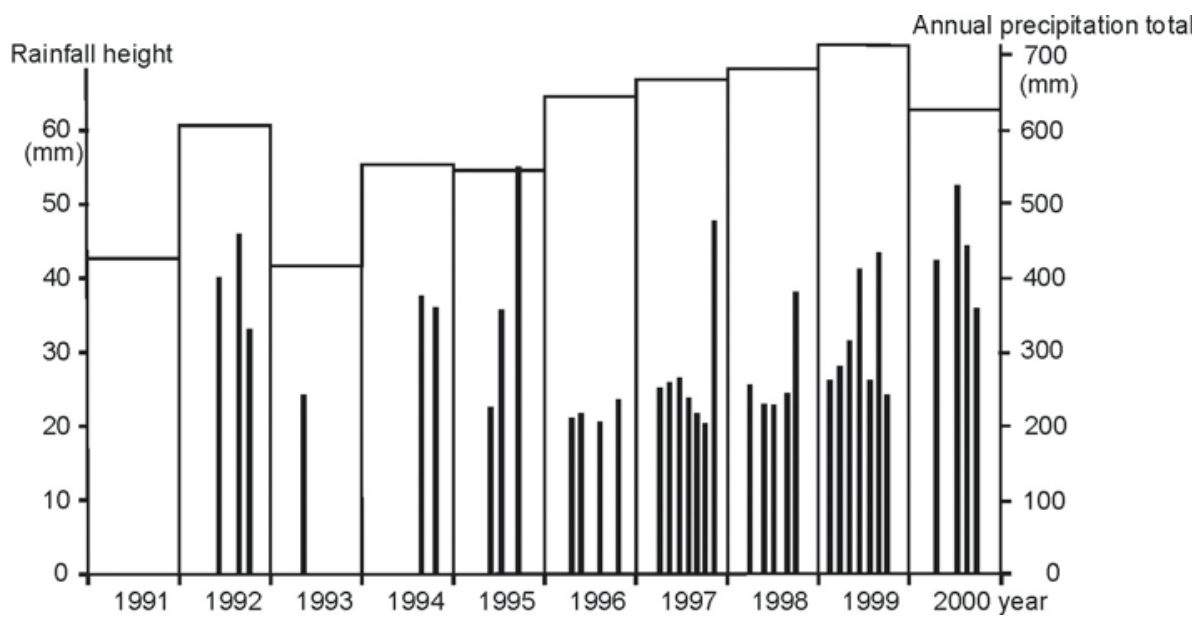

Fig. 2. Numbers and sum of the insensitive precipitation against the annual precipitation total background in the Czesławice precipitation station (NW part of the Lublin Upland) in the years 1991-2000 (Data from the Agrometeorology Department, University of Life Sciences in Lublin)

In the period analysed, also the frequency of heavy precipitation increased $(>10 \mathrm{~mm})$, and numerous violent downpours occurred $(>50 \mathrm{~mm} / \mathrm{h})$. In the area of the Lublin Upland, 12 such events were recorded (Tab. 2), determining the in- 
crease of annual precipitation totals registered in individual meteorological stations to a large extent (Rodzik, Janicki 2003; Janicki et al. 2010).

Table 2. List of downpours with extreme geomorphological effects, registered in the eastern part of the Polish Uplands in the years 1995-2000

\begin{tabular}{|c|c|c|c|c|c|}
\hline No. & Event date & Event place & Rainfall $[\mathbf{m m}]$ & Time & Erosion $^{1}$ \\
\hline 1 & 16.09 .1995 & Gutanów/Garbów & $56.9(60-70)^{2}$ & $14^{00}-16^{00}$ & very high \\
\hline 2 & 7.05 .1996 & Zubowice & $40(60-80)$ & $18^{40}-19^{20}$ & very high \\
\hline 3 & 11.05 .1996 & Turka & $(50)$ & - & very high \\
\hline 4 & 15.05 .1996 & Niedrzwica Duża & $30(>50)$ & - & very high \\
\hline 5 & 13.07 .1997 & Kazimierz Dolny & - & $2^{00}-2^{20}$ & high \\
\hline 6 & 4.08 .1997 & Okale & 57.6 & $14^{25}-15^{15}$ & high \\
\hline 7 & 4.08 .1997 & Kawęczyn & 45 & $16^{00}-18^{00}$ & high \\
\hline 8 & 6.09 .1997 & Celejów & - & $17^{00}-17^{30}$ & high \\
\hline 9 & 21.06 .1999 & Krasne & $50(80)$ & $19^{00}-20^{00}$ & very high \\
\hline 10 & 10.08 .1999 & Krynice & $64(80)$ & $18^{40}-19^{50}$ & very high \\
\hline 11 & 7.06 .2000 & Kawęczyn & - & - & high \\
\hline 12 & 7.06 .2000 & Krynice & 50 & $2^{00}-3^{00}$ & high \\
\hline
\end{tabular}

1 - intensity of erosion: a) high - max. 100-500 $\mathrm{t} \cdot \mathrm{km}^{-2}$ from gully catchment or $<100 \mathrm{t} \cdot \mathrm{km}^{-2}$ from small agricultural catchment, locally $<100 \mathrm{t} \cdot \mathrm{ha}^{-1}$ (road gully, cultivated field); b) very high - max. 500-1,000 t $\mathrm{km}^{-2}$ from gully catchment and small agricultural catchment, locally $100-1,000 \mathrm{t} \cdot \mathrm{ha}^{-1}$ (road gully, cultivated field) ${ }^{2}$ - total daily precipitation registered in the nearby precipitation station; in brackets - maximum estimated precipitation

\section{Ephemeral landforms, its time duration and classification}

Due to their sizes, landforms resulting from violent slopewash can be classified as nanorelief with vertical dimension of $10^{-6}-10^{-3} \mathrm{~km}$ (Brunsden 1996), traditionally divided into three groups:

1. macroforms (episodic channels, main rills, landslides, colluvium covers) with dimensions: $\varnothing>1 \mathrm{~m}^{2}$;

2. mesoforms (erosion rills, colluvium fans, evorsive pothols) - with dimensions: $1 \mathrm{dm}^{2}<\varnothing<1 \mathrm{~m}^{2}$;

3. microforms (microrills, notches, kettles, breaches, and erosion tanks, current lineation forms, microfans, ablation covers, microterraces, ripple marks) with dimensions: $\varnothing<1 \mathrm{dm}^{2}$.

Intensive slopewash activated a system of slopewash processes (soil erosion) in the slope system. On fields with no plant cover, rainsplash, linear erosion (= rill 
erosion), and (re)deposition processes commonly occurred. Rainsplash particularly intensively shaped hilltops and slopes of trough valleys, and short redeposition resulted in the development of a rainsplash-slopewash crusts. Linear erosion led to the development of numerous small erosion forms with a profile of $<1 \mathrm{dm}^{2}$, usually described as notches of microrills. In the case of insignificant linear flow, rills developed with the channel shape index ( $F$ - calculated as river channel) amounting to: $F=0.4-5$. Main rills with the average width of $0.3 \mathrm{~m}$ and relatively high depth (averaging $0.2 \mathrm{~m}$ ) often had an uneven profile with numerous erosion kettles, which suggests turbulent and violent flow. Rill flow was usually distinguished by high erosion rates, and the mean shear stress and unit stream power reaches significant values (Rodzik, Janicki 2003). As a result of flow concentration and increase in its rate down the slope, rill flow caused cross-grading of the areas between rills, and erosion rills transformed into main rills with the channel shape index $(F)$ of: $F=4-10$.

In the lower part of the slope "episodic channel" flow developed (shape index $F>20$ ) as a result of rill flow concentration. Episodic channels resemble beds of episodic propluvial streams (Teisseyre 1994; Rodzik et al. 1998; Rodzik, Janicki 2003). The minimum alimentation area of episodic channels averaged 5-10 ha, and in exceptional cases (high inclination, lack of plant cover), as much as $1.5 \mathrm{ha}$ (Janicki, Zgłobicki 1998). The minimum channel-forming discharge is estimated as approximately $0.1 \mathrm{~m}^{3} \cdot \mathrm{s}^{-1}$. It is usually higher, and amounts to $0.5-1 \mathrm{~m}^{3} \cdot \mathrm{s}^{-1}$. Channel flow occurs in wide $(w=1-20 \mathrm{~m})$ and shallow forms $(d<0.3 \mathrm{~m}$,), and depending on the plant cover, violent (root crops, papilionaceous plants, cereals) or even (grass) flow occurs. In exceptional conditions, channel flow, e.g. resulting from draining of slope retention microreservoirs, occurs in the "chutes and pool" phase, cutting through the channel bed with smaller erosion forms (potholes, breaches, and tanks).

A prevailing part of material shifted from slopes and floors of dry valleys during violent slopewash is deposited at the base of slopes in the form of colluvium fans with a radius of max. several tens of meters. In places with a slighter inclination, at the boundaries of cultivated fields, and at local erosion base levels (cultivated terraces, footslopes, valley floors), colluvium microfans with varied sizes developed. Their radius rarely exceeded $1 \mathrm{~m}$, and their thickness usually reached several centimetres. At gully mouths, fans developed, composed of heterogenic material of cover formations and the underlying bedrock (mainly gravels and boulders of Upper Cretaceous rocks). Their surface areas reached significant values at the level of several hundreds of square meters, and their thickness reached up to a dozen or so centimetres (Rodzik, Janicki 2003). In zones of forced deposition, often as a result of division of the valley floor with a road embankment, on dry valley floors, vast fields and colluvium covers developed, with a surface area of 
up to 1 ha and thickness of 10-20 cm. The maximum thickness of a single colluvium accumulation in favourable conditions reached as much as $0.5 \mathrm{~m}$ (Janicki, Zgłobicki 1998).

During heavy rainfalls, only attenuate (Newton) water and material flow was observed. No large scale earth or mud flow processes were determined. Exceptionally, on sod-covered slopes of road gullies and strongly inclined slopes of erosion cuts, development of shallow landslides (slides and slumps) was observed. It seems that the dominating direction of cultivation, along-slope or slanting-slope, consistent with the inclination, facilitated slopewash, and infiltration processes were restrained mainly by the shallow range of soil erosion, usually reaching the so-called plough pan, which did not favour fluidification of masses (Teisseyre 1994; Rodzik et al. 1998).

The resulting forms usually had a short "time duration" below one year. In exceptional cases, those ephemeral forms could survive for more than one year. They were usually removed as a result of agrotechnical activities. Sometimes, levelling required application of heavy equipment (bulldozer), and in the case of cuts in valley floors, they were filled with material like gravel (Janicki et al. 2002). In three cases (Niedrzwica, Krasne, Krynice), the largest erosion forms, developed during heavy rainstorms on dry valley bottoms, were not levelled. The zones were excluded from agricultural use in the case of cultivated fields (Niedrzwica and Krynice), or communication in the case of a dirt road (Krasne). On abandoned fields pioneer plants were observed. Depending on the habitat, those were usually: birch and pine (loess), and willow (sands). Edges of the erosion forms were stabilised during $2-3$ years, and biogenic accumulation occurs on their floors. After 5 years, the land forms are still visible.

\section{Rate and directions of slopewash development}

During violent downpours, vast amounts of material (Tab. 3) were transported in a very short time (from one to a dozen or so hours). The total mass of eroded material in the slope catchments analysed ranged from 225 to $5,000 \mathrm{~m}^{3}$, and was dependent on the catchment size, its relief, and landscape type. The highest rate was recorded within catchments of trough valleys (Delle) in loess areas, and the lowest in denudative trough in siliceous-carbonaceous areas. Unit erosion index (from 49 to $1,640 \mathrm{~m}^{3} \cdot \mathrm{km}^{-2}$ ) was several times higher than during secular processes, and correspond with mean annual erosion index $(0.1-0.2 \mathrm{~mm} / \mathrm{year})$ obtained by means of geodesic measurements (Mazur 1960, 1972; Mazur, Pałys 1991, 1992) for small loess catchments. Similar indexes were provided by Maruszczak et al. (1992) for small river catchments $\left(<\right.$ several tens of $\left.\mathrm{km}^{2}\right)$ as results of an analysis of suspension concentration. According to some scholars, the maximum annual soil erosion on the Lublin Upland was higher, and ranged from 2 to $17 \mathrm{~mm}$ (Mazur, Pałys 1985; Zgłobicki 2002). 
The rate of relief forming processes during violent downpours was comparative to effects of violent winter snowmelt (Janicki et al. 2010), and to effects of annual tillage erosion - the main process modelling modern slopes in agricultural areas (Twardy 1995; Zgłobicki 2002; Poesen et al. 2003). On cultivated loess slopes in the NW part of the Lublin Upland, Rejman (2006) determined the rate of tillage erosion at the level of 4-6 mm, depending on the inclination and agrotechnique applied.

Table 3. Erosion-deposition balance of the research areas

\begin{tabular}{|c|c|c|c|c|c|c|c|}
\hline No. & Study area & $\begin{array}{c}\text { Area } \\
{\left[\mathbf{k m}^{2}\right]}\end{array}$ & $\begin{array}{c}\text { Erosion } \\
\text { index } \\
\text { [mm] }\end{array}$ & $\begin{array}{l}\text { Total ero- } \\
\text { sion }\left[\mathrm{m}^{3}\right]\end{array}$ & $\begin{array}{c}\text { Deposition } \\
{\left[\mathrm{m}^{3}\right]}\end{array}$ & $\begin{array}{c}\text { Unit ero- } \\
\text { sion }\left[\mathbf{m}^{3}\right. \\
\left.\mathbf{k m}^{-2}\right]\end{array}$ & Balance \\
\hline I & \multicolumn{7}{|c|}{ Loess landscape } \\
\hline 1 & Kol. Gutanów & 0.02 & 1.70 & 332 & 332 & 1640 & 0 \\
\hline 2 & Garbów: & 2.54 & 0.60 & 1356.3 & 1309 & 534 & -47.3 \\
\hline $2 \mathrm{a}$ & Garbów I & 1.84 & 0.50 & 701.4 & 958 & 520 & +256.6 \\
\hline $2 b$ & Garbów II & 0.70 & 0.70 & 654.9 & 491 & 936 & -163.9 \\
\hline 3 & Zubowice: & 39.30 & 0.12 & 4966.3 & 4976 & 126.6 & +9.7 \\
\hline $3 a$ & Komarów & 23.80 & 0.08 & 1797.3 & 2037 & 75.5 & +239.7 \\
\hline $3 b$ & Zubowice & 15.50 & 0.20 & 3169 & 2939 & 204.4 & -230 \\
\hline 4 & Krasne & 2.80 & 0.17 & 496 & 478 & 177 & 18 \\
\hline 5 & Krynice & 0.80 & 0.68 & 550 & 410 & 687.5 & -140 \\
\hline II & \multicolumn{7}{|c|}{ Carbonaceous-siliceous landscape } \\
\hline 6 & Turka & 5.7 & 0.21 & 1210 & 1210 & 212 & 0 \\
\hline 7 & \multicolumn{7}{|c|}{ Niedrzwica Duża: } \\
\hline $7 \mathrm{a}$ & Niedrzwica I & 3.5 & 0.11 & 420 & 420 & 114 & 0 \\
\hline $7 \mathrm{~b}$ & Niedrzwica II & 3.8 & 0.05 & 225 & 225 & 49 & 0 \\
\hline
\end{tabular}

During extreme events, the rate of morphological events were very changeable. Hilltops and slightly inclined slopes were subject to the lowest degree of transformation. Concave slope elements (slope troughs) were transformed to a greater extent, particularly those with no plant cover. In those flow concentration zones the erosion rate was the highest, and valleys were deepened at a rate 
estimated as 3-6 mm/episode. Dry valley floors (Tilke), bottoms of road gullies, and cultivated scarps were subjects to the strongest transformations (Tab. 4). The erosion rate in those landforms was one order level higher than in other zones of the slope system, and reached the maximum of 10-20 cm/episode, which was equivalent to the mean multi-annual erosion rate in loess gullies, estimated as approximately several cm/year (Rodzik et al. 2008).

Table 4. Maximum real denudation in the selected partial catchments in the Zubowice (no. 1-4) and Kolonia Gutanów (no. 5) area

\begin{tabular}{|c|l|c|c|c|}
\hline No. & Objects & Area $[\mathbf{h a}]$ & Erosion $\left[\mathbf{m}^{3}\right]$ & Erosion index $[\mathbf{m m}]$ \\
\hline 1 & sugar-beet field & 0.23 & 12.3 & 5.02 \\
2 & road gully & 0.20 & 127.7 & 63.85 \\
3 & road gully & 0.15 & 108 & 72.97 \\
4 & road gully & 0.12 & 92 & 76.66 \\
5 & road gully & 0.06 & 94 & 152 \\
\hline
\end{tabular}

Footslopes and dry valley floors were usually subject to deposition. Only in the zone of loess edges, prevalence of transport over deposition, and removing of material outside the catchment was recorded. In other slope systems, the prevailing part of eroded material remained within the catchment, and the volumes of removing material outside the catchment were very small. Those observations documented the weak relation (coupling) between slopewash systems and river (channel) systems, even during extreme events (Froehlich 1982; Froehlich, Słupik 1986; Maruszczak 1986; Kostrzewski et al. 1989; Święchowicz 2002, 2008; Zgłobicki 2002; Smolska 2005).

\section{DISCUSSION AND CONCLUSIONS}

During violent downpours in the summer season in the area of the Lublin Upland, the system of rainpaths and drainageways was restored due to the development of a network of erosion rills and episodic channels (Bryan 1987; Teisseyre 1994). In the lower part of the slope, development of erosion rills led to increasing overland flow roughness, and finally to minimisation of its energy expenditure. At the slope base and on along-slope main valley floors, the flow balance was obtained in the opposite manner, through a decrease in the roughness coefficient as a result of slopewash deposition. As a consequence, the processes facilitated reaching the dynamic balance of slope (Kirkby 1971, 1978; Teisseyre 1994).

During violent downpours, Horton overland flow initiates intensive soil erosion processes in the slope system (Bennett 1939; Zachar 1982). Concave slope forms with no plant cover consolidated and accelerated propluvial flow, which led 
to dissection of their bottoms (Kirkby 1971; Teisseyre 1994). A typical group of erosion microforms have developed: erosion rills and episodic channels, often described in the literature as summer ephemeral gullies (Nachtergaele, Poesen 1999; Nachtergaele et al. 2001; Poesen et al. 2003; Valentin et al. 2005). Erosion usually reaches the plough layer (Bennett 1939), and only in exceptional cases, subsoil and soil substratum are dissected (Fig. 3). An individual event also rarely results in the development of a (micro)gully (Janicki et al. 2002; Rodzik et al. 2008). Dry valley floors during a heavy rainstorm usually constitute zones of aggradation of material coming from eroded slopes and valley slopes.

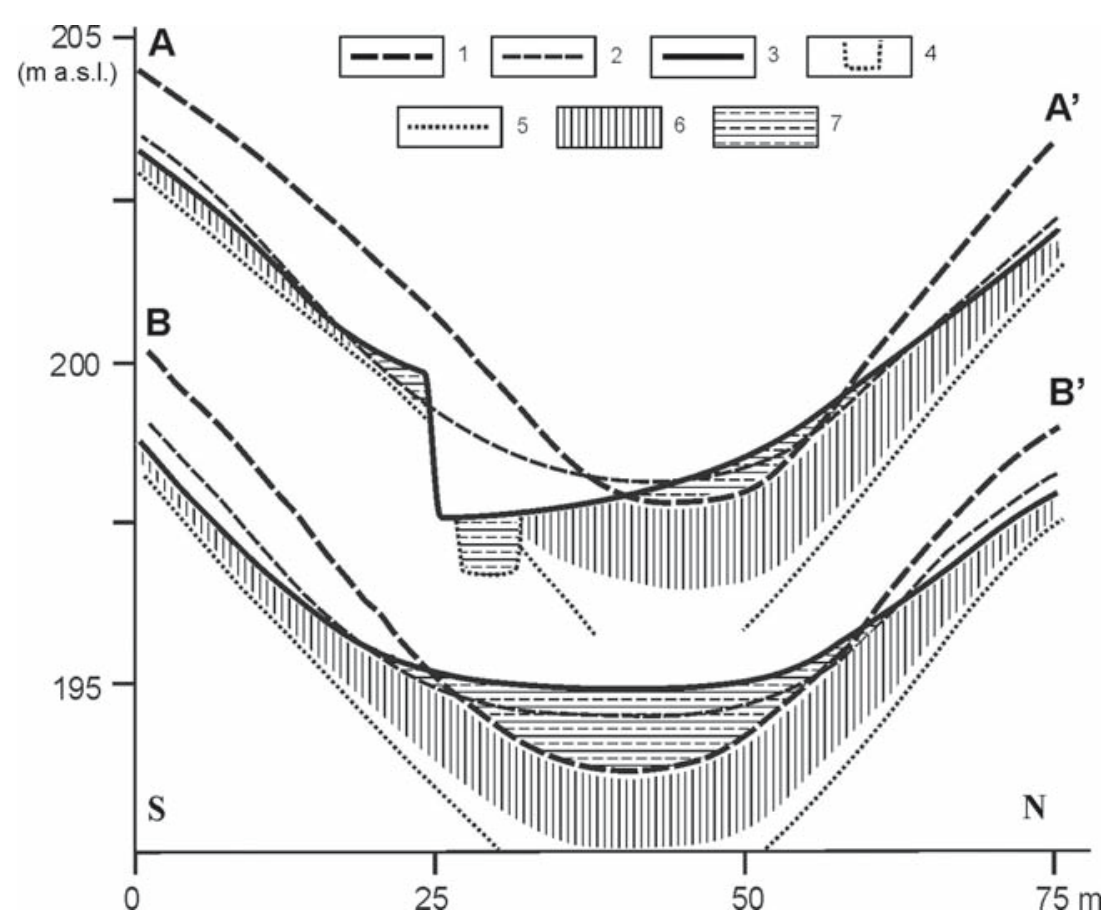

Fig. 3. The soil transects across trough valley [study area: Kolonia Gutanów]:

A-A' - influence of the agricultural scarp on the through bottom transformation [middle part of valley], B-B' - trough valley mouth; 1 - initial surface, 2 - surface approximately 50 years ago, 3 - recent topographic surface, 4 - buried potholes and dissections, 5 - loess decalcification boundary, 6 - soil, 7 - colluvium

During extreme events, 225 to c.a. $5,000 \mathrm{~m}^{3}$ of material was removed and transported within the slope systems of the Lublin Upland, and the thickness of the removed layer averages from $0.17 \mathrm{~mm}$ to $1.7 \mathrm{~mm}$, and in extreme cases even up to $150 \mathrm{~mm}$. The highest individual erosion rate was observed during a violent downpour in the loess catchment $\left(1,640 \mathrm{~m}^{3} \mathrm{~km}^{-2}\right)$. In the carbonaceous-siliceous 
landscape, the index reached significantly lower values $\left(225-1210 \mathrm{~m}^{3} \cdot \mathrm{km}^{-2}\right)$. This results from the downpour's efficiency and geological-morphological factors making loess areas very sensitive and prone to erosion (Rodzik, Janicki 2003; Rodzik et al. 2008).

In a medium timescale, in the majority of areas of the Lublin Upland, bottoms of troughs and dry valley floors are currently subject to deposition, and not deepening processes, as Teisseyre (1994) determines for the loess regions of SW Poland. It is evidenced by soil profiles extended by colluvium on valley floors (Klimowicz, Uziak 2001). In exceptional cases, dry valley floors can be lowered, but effects of the process are quickly covered up by the development of secular processes, including tillage erosion (Janicki et al. 2002; Rodzik et al. 2008). In a short timescale, the slope relief is subject to planation, and the steepness and denivelation decreases along with an increase in the length of slopes (Fig. 3).

Hilltop hummocks and convex divergent slopes are subject to downwearing, whereas concave convergent slopes and dry valley floors - to deposition. Frequent occurrence of linear erosion in a given place can lead to development of an ablation through (Horton 1945; Leopold et al. 1946). Such forms cause further dissection of the slope, and its backwearing. Generally, however, in slopewash systems, slope and hilltop erosion, and extension of colluvium fans predominate. Slopewash systems are therefore distinguished by the co-occurrence of the processes of lowering and peneplenation, and slope backwearing and pedimentation (Sobolew 1948; Gerlach 1966, 1976, Teisseyre 1994; Janicki et al. 2002, Rodzik et al. 2008).

\section{ACKNOWLEDGEMENTS}

The paper was prepared within the framework of the research project "Extreme hydroclimatic events in Poland" (PBZ-KBN-086/PO4/2003), supported by the Polish Ministry of Science and Higher Education.

\section{REFERENCES}

Bennett H.H., 1939: Soil Conservation. Mc Graw-Hill Book Co., New York-London (2 ${ }^{\text {nd }}$ edition 1955), Element of soil conservation, 1-993.

Buraczyński J., 1992: Przebieg i skutki gwałtownej ulewy w Dzierzkowicach na Wyżnie Lubelskiej. Annales UMCS, Sec. B. 1989/1990, 44/45, 95-104 .

Brunsden D., 1996: Geomorphological events and landform change. Zeitschrift für Geomorphologie, 40, 3, 273-288.

Bryan R.B., (ed.) 1987: Rill erosion. Processes and significance. Catena Supplement, 8, Braunschwieg, 1-160.

Davis W.M., 1899: The geographical cycle. Geographical Journal, 14, 481-504. 
Dylik J., 1969: Slope development under periglacial conditions in the Łódź region. Biuletyn Peryglacjalny, 18, 381-410 .

Froehlich W., 1982: Mechanizm transportu fluwialnego i dostawy zwietrzelin do koryta w górskiej zlewni fliszowej. Prace Geograficzne IGiPZ PAN, 143, 1-144.

Froehlich W., Słupik J., 1986: Rola dróg $w$ ksztattowaniu spływu i erozji w karpackich zlewniach fliszowych. Przegląd Geograficzny, 58, 67-87 .

Gerlach T., 1966: Współczesny rozwój stoków w dorzeczu górnego Grajcarka (Beskid Wysoki-Karpaty Zachodnie). Prace Geograficzne IG PAN, 52, 1-111.

Gerlach T., 1976: Wspótczesny rozwój stoków w polskich Karpatach fliszowych. Prace Geograficzne IG i PZ PAN, 122, 1-116.

Harasimiuk M. 1980: Rzeźba strukturalna Wyżyny Lubelskiej i Roztocza. Wyd. Uniwersytetu Marii Curie-Skłodowskiej, Lublin, 1-136.

Horton R.E., 1945: Erosional development of streams and their drainage basins: hydrophysical approach to quantitative morphology. Bulletin of the Geological Society of America Proceedings, 3, 275-370.

Jahn A., 1956: Wyżyna Lubelska. Rzeźba i czwartorzęd. Prace Geograficzne IG PAN, 7, 1-453 .

Janicki G., 2002: Wpływ zdarzeń katastrofalnych na funkcjonowanie systemu deluwialnego na przykładzie Wyżyny Lubelskiej. Maszynopis Zakładu Geoekologii i Paleogeografii, Uniwersytet Marii Curie-Skłodowskiej, Lublin, 1-294 .

Janicki G., Kociuba W., Rodzik J., Zgłobicki W., 2010: Ekstremalne procesy geomorfologiczne we wschodniej części Wyżyn Polskich - warunki występowania i oddziaływanie na rzeźbę. Prace i Studia Geograficzne, 45, 11-28 .

Janicki G., Rodzik J., Zgłobicki W., 2002: Geomorphic effects of land use changes (a case of the Gutanów loess catchment, Poland). Geografický časopis, 54, 1, 39-57.

Janicki G., Zgłobicki W., 1998: Geomorfologiczne skutki ulewy (z 16.09.1995 r.) w okolicy Garbowa na Wyżnie Lubelskiej. Annales UMCS, sec. B, 53, 109-129.

Kaszewski B.M., 2008: Warunki klimatyczne Lubelszczyzny. Maria Curie-Skłodowska University Press, Lublin, 1-60 .

Kaszewski M., Mrugała S., Warakomski W., 1995: Klimat. 1: Temperatura powietrza i opady atmosferyczne na obszarze Lubelszczyzny (1951-1990). In: (eds.) R. Turski, S. Uziak, Środowisko przyrodnicze Lubelszczyzny, Wyd. LTN, Lublin, 1-67.

Kirkby M.J., 1971: Hillslope procces-response models based on the continuity equation. Institute of British Geographers Special Publications, 3, 15-30.

Kirkby M. J., (ed.) 1978: Hillslope Hydrology, John Wiley and Sons. Ltd., Chichester, 1-389.

Klimowicz J., Uziak S., 2001: The influence of long-term cultivation on soil properties and patterns in an undulating terrain in Poland. Catena, 43, 177-189.

Kostrzewski A., Klimczak R., Stach A., Zwoliński Z., 1989: Morphologic effects of heavy rainfall (24 May, 1983) over relief features of the scarpland in the middle Parsetta valley, West Pomerania, Poland. Quaestiones Geographicae, Spec. Issue 2, 101-110.

Lach J, 1984: Geomorfologiczne skutki antropopresji rolniczej w wybranych częściach Karpat i Przedgórza. Prace Monograficzne WSP, 66, Kraków, 1-142 .

Leopold L.B., Wolman M.G., Miller J.P., 1964: Fluvial Processes in Geomorphology. W. H. Freeman \& Co., San Francisco, 1-522.

Maruszczak H., 1972: Wyżyny Lubelsko-Wotyńskie. In: (ed.) M. Klimaszewski, Geomorfologia Polski 1, PWN, Warszawa, 340-383 .

Maruszczak H., 1973: Erozja wąwozowa we wschodniej części wyżyn poludniowopolskich. Zeszyty Problemowe Postępu Nauk Rolniczych, 151, 15-30 .

Maruszczak H., 1986: Tendencje sekularne i zjawiska ekstremalne w rozwoju rzeźby małopolskich wyżyn lessowych w czasach historycznych. Czasopismo Geograficzne, 57, 2, 271-282 . 
Maruszczak H., 2001: Rozwój rzeźby wschodniej części wyżyn metakarpackich w okresie posarmackim. Przegląd Geograficzny, 3, 253-280 .

Maruszczak H., Rodzik J., Świeca A., 1992: Denudacja mechaniczna i chemiczna we wschodniej części pasa wyżyn poludniowopolskich. In: (ed.) A. Kotarba, System denudacyjny Polski, Prace Geograficzne IGiPZ PAN, 155, 105-133 .

Mazur Z., 1960: Określenie natężenia erozji wodnej na terenie lessowym Zakładu Rolno-Doświadczalnego Elizówka. Annales UMCS, Sec. E, 13, 145-193.

Mazur Z., 1972: Zmiany rzeźby uprawnych zboczy lessowych w Elizówce. Annales UMCS, Sec. E, 27, 169-180 .

Mazur Z., Pałys S., 1985: Wplyw erozji wodnej na morfologię i zmienność pokrywy glebowej terenów lessowych, Zeszyty Problemowe Postępu Nauk Rolniczych, 292, 21-37 .

Mazur Z., Pałys S., 1991: Natężenie erozji wodnej w matych zlewniach terenów lessowych Wyżyny Lubelskiej w latach 1986-1990. In: Erozja gleb i jej zapobieganie, Wyd. AR, Lublin, 63- 78 .

Mazur Z., Pałys S., 1992: Erozja wodna w zlewni lessowej na Lubelszczyźnie w latach 1956-1991. Annales UMCS, sec. E, 47, 219-229 .

Nachtergale J., Poesen J., 1999: Assessment of soil losses by ephemeral gully erosion using highalitude (stereo) aerial photographs. Earth Surface Processes and Landforms, 24, 693-706.

Nachtergaele J., Poesen J., Steegen A., Takken I., Beuselinck L., Vandekerckove L., Govers G., 2001: The value of a physically based model versus an empirical approach in the prediction of ephemeral gully erosion for loess-derived soils. Geomorphology, 40, 237-252.

Poesen J., Nachtergaele J., Verstraeten G., Valentin C., 2003: Gully erosion and environmental change: importance and research needs. Catena, 50 (2-4), 91-133.

Rejman J., 2006: Wpływ erozji wodnej i uprawowej na przeksztatcenie gleb i stoków lessowych. Acta Agrophysica, 136, Rozprawy i Monografie 3, 1-90 .

Rodzik J., 1999: Wpływ geometrii stoku na erozję gleb uprawnych, In: (eds.) R. Dębicki, J. Chodorowski, Rola gleby w funkcjonowaniu ekosystemów, Materiały kongresu Polskiego Towarzystwa Gleboznawczego oraz międzynarodowej konferencji naukowej, Lublin 7-10 września 1999, Instytut Agrofizyki PAN, Lublin, 335-336 .

Rodzik J., 2000: Klasyfikacja form drogowych na obszarach lessowych. In: (eds.) L. Andrzejewski, P. Molewski, W. Wysota, Dorobek i pozycja polskiej geomorfologii u progu XXI wieku, V Zjazd Geomorfologów Polskich, Toruń, 11-14 września 2000 r., Wyd. UMK, 194-195 .

Rodzik J., Ciupa T., Janicki G., Kociuba W., Tyc A., Zgłobicki W., 2008: Współczesne przemiany rzeźby Wyżyn Polskich. In: (eds.) A. Kotarba, A. Kostrzewski, K. Krzemień, L. Starkel, Wspótczesne przemiany rzeźby Polski, Wydawnictwo Instytutu Geografii i Gospodarki Przestrzennej Uniwersytet Jagielloński, Kraków, 165-228.

Rodzik J., Janicki G., 2003: Local downpours and their erosional effects. Papers on Global Change IGBP, National IGBP-Global Change Committee, 10, 49-66.

Rodzik J., Janicki G., Zagórski P., Zgłobicki W., 1998: Deszcze nawalne na Wyżynie Lubelskiej i ich wplyw na rzeźbę obszarów lessowych. In: (ed.) L. Strakel, Geomorfologiczny i sedymentologiczny zapis lokalnych ulew, Dokumentacja Geograficzna, 11, 45-68 .

Smolska E., 2005: Znaczenie splukiwania w modelowaniu stoków młodoglacjalnych (na przykładzie Pojezierza Suwalskiego. WGSR UW, Warszawa, 1-146.

Sobolew S.S., 1948: Razwitije erozionnych processow na tieritori jewropieiskoj czasti SSSR i borba s nimi. Vol. I, Acad. Science of SSSR, Moscow, 1-306.

Starkel L., 1976: The role of extreme (catastrophic) event in contemporary evolution of slopes, In: (ed.) E. Debryshire, Geomorphology and Climate, Wiley, London, 203-246.

Starkel L., 1986: Rola zjawisk ekstremalnych i procesów sekularnych w ewolucji rzeźby (na przykładzie fliszowych Karpat). Czasopismo Geograficzne, 57, 2, 203-213 .

Starkel L., 2005: Anthropogenic soil erosion since the Neolithic in Poland. Zeitschrift für Geomorphologie, N.E., Suppl., 139, 189-201. 
Święchowicz J., 2002: Wspótdziałanie procesów stokowych i fluwialnych w odprowadzaniu materiału rozpuszczonego i zawiesiny ze zlewni pogórskiej. Instytut Geografii UJ, Kraków, 1-150 .

Święchowicz J., 2008: Soil erosion on cultivated foothill slopes during extreme rainfall events in Wiśnicz Foothills of southern Poland. Folia Geographica, series Geographica-Physica, 39, 80-93.

Teisseyre A.K., 1994: Splyw stokowy i wspótczesne osady deluwialne w lessowym rejonie Henrykowa na Dolnym Ślasku. Acta Universitatis Wratislaviensis Prace Geologiczno-Mineralogiczne, 43, 1-188.

Twardy J., 1995: Dynamika denudacji holoceńskiej w strefie krawędziowej Wyżyny Łódzkiej. Acta Geographica Lodziensia, 69, 1-213 .

Valentin C., Poesen J., Yong Li., 2005: Gully erosion: impacts, factors and control. Catena, 63, $132-153$

Wojtanowicz J., 1999: Europa Środkowa jako region fizycznogeograficzny - podstawy wydzielenia, granice. Przegląd Geograficzny, 3, 211-223 .

Zgłobicki W., 2002: Dynamika wspótczesnych procesów denudacyjnych w pótnocno-zachodniej części Wyżyny Lubelskiej. Wyd. UMCS, Lublin, Lublin, 1-159 .

Zachar D., 1982: Soil Erosion. Elsevier, Amsterdam, 1-547.

\section{STRESZCZENIE}

Przedmiotem badań były przeobrażenia i zmiany kierunkowe stoków zbudowanych z czwartorzędowych osadów pylastych i piaszczysto-pylastych. Stoki te, odziedziczone po morfogenezie plejstoceńskiej, są współcześnie modelowane przede wszystkim przez procesy zmywu powierzchniowego i erozji gleb. Badania na rozwojem tego typu stoków były prowadzone w latach 1995-2000 na Wyżynie Lubelskiej (sensu lato) w różnych typach krajobrazu. Badania obejmowały analizę funkcjonowania systemów stokowych podczas gwałtownych spływów propluwialnych oraz polową analizę profili glebowych w wybranych zlewniach epizodycznych (ryc. 1).

W badanym okresie zanotowano na Wyżynie Lubelskiej dużą liczbę obfitych opadów (ryc. 2) oraz 12 gwałtownych ulew (tab. 2), które wywołały intensywny spływ powierzchniowy oraz lokalne wezbrania i powodzie w dnach małych dolin rzecznych. W zlewniach epizodycznych zarejestrowano zaś rozwój efemerycznych form rzeźby terenu (nanorelief). Podczas tego typu zdarzeń w analizowanych zlewniach przemieszczane były w bardzo krótkim czasie duże ilości materiału stokowego (od $225 \mathrm{~m}^{3}$ do $5000 \mathrm{~m}^{3}$ ), a wskaźnik erozji jednostkowej wynosił od 49 do $1640 \mathrm{~m}^{3} \cdot \mathrm{km}^{-2}$ (tab. 3). Natężenie erozji wynosiło średnio $0,1-0,2 \mathrm{~mm} /$ epizod i było porównywalne do średniej rocznej erozji w małych zlewniach użytkowanych rolniczo. Lokalnie natężenie erozji było znacznie wyższe (10-12 cm/epizod), głównie w obrębie wąwozów drogowych (tab. 4).

Podczas gwałtownych ulew erodowane były głównie wklęsłe i zbieżne stoki i zbocza dolin nieckowatych. U podnóża stoków i w dnach dolin walnych większość wyerodowanego materiału była deponowana w postaci stożków i pokryw deluwialnych. W wyjątkowych sytuacjach dochodziło do rozcinania i rozczłonkowywania stoków. Powstałe zaś efemeryczne formy rzeźby stokowej były szybko niwelowane głównie przez zabiegi agrotechniczne.

Intensywne spływy związane z gwałtownymi ulewami prowadzą więc do obniżania i spłaszczania stoku, a w konsekwencji do łagodzenia rzeźby. W krótkiej skali czasu dominuje planacja stoków, której towarzyszy niekiedy mikropedymentacja i cofanie stoków, a wyjątkowo tylko dochodzi do rozwoju (mikro)wąwozów. Przeprowadzone badania wykazały stosunkowo dużą stabilność systemów stokowych w krótkiej skali czasu nawet w warunkach dużej presji rolniczej. 